\title{
"Impact of Brexit on Global Economy"- An Attempt to Guide Investor Based on Empirical Study
}

\author{
Santhosh.CH ${ }^{1}$, Radhakrishna Nayak ${ }^{2}$ \\ ${ }^{1} 1^{\text {st }}$ M.com Dept. of P.G Studies in Commerce St Aloysius College, Mangalore \\ ${ }^{2}$ Asst. Professor, Dept. of P.G Studies in Commerce St Aloysius College, Mangalore
}

\begin{abstract}
The United Kingdom's withdrawal from the European Union is widely known as Brexit, a portmanteau of "British" and "Exit". Following a referendum held on 23 June 2016, in which 52\% of votes cast were in favor of leaving the EU, the UK government intends to invoke Article 50 of the Treaty on European Union by the end of March 2017. This, within the treaty terms, would put the UK on a course to leave the EU by March 2019. Banks across Europe and the US have been battered by Brexit. Shares in big global banks outside the UK fell anywhere from 7 to 20 percent on the day after the UK voted to quit the EU. Though other parts of the market have since recovered, non-UK banks have failed to make back all of their losses. Brexit played significance role in the movement of the world top recognized stock exchanges. Investors started to step back from their share market investments. Even in India, severe effect of Brexit have been experienced by the entire financial system and by all most all individual companies of different industrial sector. "Britain always provided a gateway to the European Union. Many Indian businesses have their offices in Britain so they can avail benefits and continue to remain a part of the EU. But with Brexit, this benefit will be taken away and may result in companies relocating their business set ups to other places" even investors also need to get insight of this for formulating better investment strategies. In this attempt authors tried to guide and educate the prospective investors on Brexit and its impact on global economy while formulating his investment strategies. Share market performance information gathered from various stock markets across the globe and 8 Indian companies before and after the Brexit market performance data for the past two years have been considered. Final interpretation and suggestions is given using different financial and statistical techniques. This attempt can be used by students, researcher, and investors and by others for investment decision and for further modified study.
\end{abstract}

Keywords: Brexit, Efficient Frontier, Indian Economy, Optimal Portfolio, World Economy.

\section{Introduction}

Way back in 1957, France, West Germany, Belgium, Italy, Luxembourg and the Netherlands signed the Treaty of Paris, which established the European Economic Community (EEC), the predecessor of today's European Union. It was the latest of several attempts to foster economic cooperation between European nations in the wake of World War II. Nations that traded together, it was believed, would be less likely to go to war with each other. During 1961 United Kingdom made an application to join European Union but due to political isolation in Western Europe, this application was vetoed by the French Government in 1963, again UK made second attempt to join EU which was again vetoed by the French in 1967. After a long waiting during 1969 there was a negotiation for British membership. The United Kingdom joined EEC on $1^{\text {st }}$ January 1973 with Denmark and Ireland. This proved controversial at the time.

The Labor party initially sought renegotiation of membership. During 1975, the nation held referendum to decide whether UK should stay in the European community / common market that showed positive sign of staying, this has led the center-left Labour party split, over the issue with the pro-Europe wing splitting from the rest of the part to form the Social democratic party(SDP). During 1984 the conflict started between EEC \& UK, when the conservative PM Margeret Thatcher gave an order to reduce British payments to the EEC Budget. The Maastricht Treaty, which took effect in 1993, created the Brussels-based European Union (EU) was the main component. The EU was designed to integrate Europe's nations politically and economically, including a united foreign policy, common citizenship rights and (for most member nations, excluding UK) a single currency, the euro. Later in 1997 Labour Prime Minister Tony Blair, was strongly pro-European Union tried to rebuild ties with the rest of the Europe.

In 2007, after plans for an official EU constitution collapsed, the member nations finished negotiating the controversial Lisbon Treaty, which gave Brussels broader powers. With the interest of protecting Britain's financial sector, David Cameron became the first UK Prime Minister to veto an EU Treaty; 2011. Against the backdrop of economic unrest in the Eurozone (territory of $19 \mathrm{EU}$ nations having Euro) and an ongoing migrant crisis, UKIP and the other supporters of a possible British exit from the EU or Brexit increased over the past several years. In 2015 Cameron went to work renegotiating the UK-EU relationship, including changes in 
migrant welfare payments, financial safeguards and easier ways for Britain to block EU regulations. In February 2016, he announced the results of those negotiations, and set June 23 as the date of the promised referendum.

\section{Impact of Brexit on World Economy And International Trade}

Brexit which means 'British' and 'exit', which was derived from the analogy from Grexit (an hypothetical withdrawal of Greece from the EU). Reflecting back on a similar situation that took place in 1861 72 years after the ratification of the Constitution in 1789 - the southern states of the United States exited the American Union. In 2016 - 70 years after Winston Churchill first called for the establishment of a United States of Europe in 1946 - Great Britain exited the European Union.In a nationwide referendum held on $23^{\text {rd }}$ June 2016, though undoubtedly a historic decision, the majority of British citizens voted for the United Kingdom to leave the European Union. In the wake of the controversial Brexit vote, financial market plunged and Britain Prime Minister David Cameron, who led the campaign to stay in the EU, announced his resignation. Brexit is also only the latest development in the conflicted relationship between the UK and the EU that has played out over the past 50 years. The consequences of this decision had led to major repercussions for India and the rest of the world and will lasts for several decades, if not generations, to come.Since Brexit, all EU members are worse off: Ireland suffers the largest proportional losses from Brexit, alongside the Netherlands and Belgium. Countries that lost the most are those who were trading the most with the UK. Some countries outside the EU, such as Russia, Turkey etc., are the gainers as trade is mostly diverted towards them and away from EU.

\section{Impact of Brexit on world's selected major stock exchanges}

Britain is one of the largest economies in the world. Where goods and services which costs billions of pounds is being imported from other countries every year, due to their declining purchase power, British consumers and businesses has decreased their imports from other countries, which is causing other economies to slowdown. For every point of decline in UK's economic growth, the other countries especially European countries are experiencing decline in their economy and also European companies are facing decrease in their profit. Therefore stock markets all across the Europe also have declined in the immediate after the Brexit vote. Brexit also caused a sharp negative reaction in other countries stock markets. For the study purpose, data on each month end stockmarket performance of following 21 Stock Exchangesincluding the market indicators which are situated throughout the worldand their securities trading values for the past 2 years( 25 months) have been taken into consideration.

* Bombay Stock Exchange [BSE Sensex]: An Indian Stock Exchange, which is the world's $11^{\text {th }}$ largest stock exchange with an overall market capitalization of \$1.43 Trillion as of March, 2016 and having more than 55000 companies being publicly listed on BSE.

* Nifty: National Stock Exchange of India Limited is the leading stock exchanges in India which was the first demutualized electronic exchange in the country and has a total market capitalization of more than US \$ 1.41Trillion. Making it the world's $12^{\text {th }}$ largest stock exchange as of March 2016.

* NASDAQ:NASDAQ Stock Market is an American stock exchange; it is the $2^{\text {nd }}$ largest exchange in the world by market capitalization of US \$ 6.8Trillion as on March 2016.

* FTSE: Financial Times Stock Exchange a subsidiary of London stock exchange group with a market capitalization of $€ 1$.7Trillion as on September 2016.

* KOSPI: The Korea Composite Stock price Index with market capitalization KRW 1538Trillion.

* Taiwan Index: It is a stock market index for the companies traded on the Taiwan stock exchange which is having a combined market capitalization of NT \$24,519,622Million.

* CAC: Is a benchmark French Stock Market index with a market capitalization of $€ 1.207$ Trillion (31 March 2016).

* DJI [Dow Jones Industrial Average]: This is also called as DJIA which is the second oldest US market Index which was created by DOW.

* SMI Switzerland: Swiss market index is Switzerland's blue chip stock market index, with a market capitalization of $€$ 783.1Billion (end 2009).

* London Stock Exchange: It is British-based Stock Exchange and financial Information Company.

* Deutsche Borse Group: A German stock exchange with a combined market capitalization of $€ 1.4$ Trillion (on 1/10/14) is the $14^{\text {th }}$ announced member of UN sustainable stock exchanges initiatives.

* HangSeng Index: Is a Free-float-adjusted market capitalization weighted stock market index in Hong Kong. It is the main indicator of the overall market performance in Hong Kong.

* Shanghai Stock Exchange: Is the stock exchange that is shaped in the city of Shanghai in China. It is the world's $5^{\text {th }}$ largest stock market by market capitalization of US \$3.5Trillion as of February 2016.

* Australian Security Exchange: Located in Sydney, Australia which operates Australia's primary securities exchange with market capitalization of A \$ 1.663Trillion (October 2016). 
* S\&P/TSX Composite Index: It is the bench mark Canadian Index presenting roughly $70 \%$ of the total market capitalization on the Toronto Stock Exchange with about 250 companies included in it.

* Tadawul Stock Exchange: Saudi Stock Exchange in Saudi Arabia, It is supervised by capital market Authority

* AEX Index: Derived from Amsterdam Exchange Index is a stock market index of Dutch companies, with a market capitalization of $€ 490.85$ Billion.

* DAX: Deutscher Aktien Index (German Stock Index) is a blue chip stock market with a market capitalization of $£ 1.018$ Trillion.

* Straits Times Index: It is a Capitalization-weighted Stock Market Index which is regarded as the bench mark index for the Singapore Stock Mark with market capitalization of S\$262,718Million (as of 28 February 2014).

* Nikkei 225: Mostly called as Nikkei Stock Average, is a stock market index for the Tokyo Stock Exchange which is the $4^{\text {th }}$ largest Stock Exchange with market capitalization of JPY ¥ 492Trillion (September 2014).

* MICEX Moscow: Moscow Exchange, the largest exchange group in Russia, with market capitalization of RUB 259Billion as on November 2016.

\section{Impact of brexit on Indian share market based on selected major companies:}

For the purpose of present study Indian Multinational Corporations which are situated or operating in European countries are taken into consideration, in order to know the exact impact of Brexit on India Companies. Following are the 8 leading Indian Companies operating in Europe.

* Infosys: An Indian Multinational Corporation which provides Business Consulting, Information Technology and Outsourcing services is the $2^{\text {nd }}$ largest Indian IT services company by 2016 revenues [US $\$ .10 .1$ billion(2016)], with a profit of US \$ 2.052 billion(2016) having operations in 14 European Countries including France, Germany, Ireland, Switzerland, United Kingdom, Netherlands, Belgium, Denmark.

* Tata Consultancy Services (TCS): Is an International Multinational company providing Information Technology service, Consulting and Business Solutions, is a subsidiary of Tata Group. It operates in 46 countries is the largest Indian companies by market capitalizations [\$.80billion (2016)] with revenue of US $\$ 16.54$ billion (2016) and profit of US \$3.70billion (2016) is among the 'Big 4' most valuable IT services brand worldwide, having operations in 21 countries including the United Kingdom, France, Germany, Austria, Switzerland, the Nordics and Benelux region.

* WIPRO: Western India Palm Refined Oils Limited or more recently "Western India Products Limited" is an Information Technology services corporation with a revenue of US \$ 7.735billion (2016) and a profit of US \$1.348billion (2016) having business operations in European countries such as Austria, Ireland, Romania, Belgium, Luxemburg, Sweden, Finland, Netherlands, Switzerland, Norway, Turkey, Germany, Poland, United Kingdom, Hungary, France and Portugal.

* Tech Mahindra Limited: The Multinational Company which is a provider of Information Technology, Networking technology solutions and Business Process Outsourcing to the telecommunications industry, with an annual revenue of US \$ 4.1billion (March 2016) and Net income of US \$ 474million (March 2016), having offices in more than 50 countries which includes 17 offices in European countries such as Belgium, Czech Republic, Denmark, Finland, France, Germany, Hungary, Ireland, Italy, Luxembourg, Netherlands, Norway, Romania, Spain, Sweden, Switzerland and United Kingdom.

* Jet Airways: It is an Airline based Indian Multinational Company, which is the $2^{\text {nd }}$ largest airline in India, as on February 2016. It operates over 300 flights daily worldwide, with a revenue of US \$ 3.2billion (2015) and having a profit of US \$ 310million (2015), operating in European countries like Belgium, France, Italy, Netherlands.

* HCL Technologies: A Multinational Information Technology Services company, is a subsidiary of HCL Enterprise, originally a research and development division of HCL, offers services including IT Consulting, Enterprise Transformation, Remote Infrastructure Management, engineering and R\&D and Business Process Outsourcing and has an annual revenue of US \$ 6.746billion (FY'17 Q3 LTM) and a profit of US \$ 1.198billion (FY'17 Q3 LTM) having operations in 34 countries including European Countries like France, Germany and Northern Ireland in the UK.

* BIOCON Limited: It is a Biopharmaceutical Company that manufactures generic active pharmaceutical ingredients, bio similar Insulin's, etc. withan annual revenue of US \$ 530million and a Net income of US \$ 140million and is having business offices in various countries including European countries like Japan, France, Brazil, Mexico, Turkey, etc.

* Mahindra \& Mahindra Limited [M\&M]: It is a Multinational automobile manufacturing corporation. It is one of the largest vehicle manufacturers by production in India and the largest manufacturer of tractors in the world, M\&M is a part of Mahindra Group having a revenue of US \$ 11billion (2015) and a net income 
of US \$390million and having a business operations in European countries like Italy, France, Greece, Hungary, Bulgaria, Serbia, Bosniaand Herzegovina, Croatia, Slovakia, Spain, Macedonia, Albania.

\section{Expected Return}

Rational investor always would like to maximize his return in given condition for a group of investment alternatives. Expected or average rate of return for a particular share to which it's maximum could be selected for the investment. Average return for any stock can be calculated as under...

Return $=((($ closing price - opening price $) /$ opening price $) * 100)$

Average Return $=(\Sigma$ Return $/ \mathrm{N})$

Where $\mathbf{N}=$ Number of observation.

\section{Standard Deviation:}

Movement from traditional view to modern view made people to think even about risk apart from return concept in investment decision. Investment decision may be more accurate if the concept of risk have considered for investment. Understanding the nature of the risk is not adequate unless the investor or analyst is capable of expressing it in some quantitative terms. Expressing the risk of a stock in quantitative terms makes it comparable with other stocks. Measurements cannot be assured of cent percent accuracy because risk is caused by numerous factors such as social, political, economic and managerial efficiency. Measurement provides an approximate quantification of risk. The statistical tool always used to measure and used as a proxy for risk is the standard deviation.

Variance $=(\text { Standard Deviation })^{2}=\sum_{i=1}^{N}(\text { Return }- \text { Average Return })^{2}$

The standard deviation represents the variation in the expected return. Higher the standard deviation higher will be the variation in the expected return and vice versa. One can select those scripts which yield very minimum variance for investment.

\section{The Concept of Beta:}

Share market movement reflects in individual companies share price and some type of the direction in the movement share price can be noted. To study the average relationship between share market movement and individual companies share price variation, the concept of beta can be used. Beta indicates that one percent change in NSE index return would cause some percent change in the stock return. Beta is calculated for individual companies using regression analysis. Beta values range between negative and positive value and each value represents different meaning.

i) Beta $=+1.0$ stock moves in tandem with market.

ii) Beta $=+0.5$ stock is less volatile compared to the market.

iii) Beta $=+2.0$ stock return is more volatile.

iv) Negative Beta value indicates that the stock return moves in the opposite direction to the market return.

Note: Stock with more than 1 Beta value is considered to be risky.

$\mathbf{B}=\left\{[\Sigma(\right.$ Return - Avg Return $) *(\mathbf{R m}-$ Avg market return $\left.)] / \Sigma(\mathbf{R m}-\text { Avg market return })^{2}\right\}$

Note: Where Rm means market return.

\section{Capital Asset Pricing Model:}

To decide about what might be the minimum return that a script should yield to satisfy current level of risk can be studied with the concept of capital asset pricing model. The risk averse nature of nature of the investors is the underlying factor for this behavior. The capital pricing theory helps the investors to understand the risk and return relationship of the securities. It also explains how assets should be priced in the capital market.

$$
\mathbf{R}_{\mathbf{i}}=\mathbf{R}_{\mathbf{f}}+\boldsymbol{\beta}\left(\mathbf{R}_{\mathrm{m}}-\mathbf{R}_{\mathrm{f}}\right)
$$

Note: Where $R f$ means risk free rate of return i.e., return given by government $T$ - bills.

The general idea behind CAPM is that investors need to be compensated in two ways: time value of money and risk. The time value is represented by the risk free $\left(\mathrm{r}_{\mathrm{f}}\right)$ rate in the formula and compensates the investors for time. The other half of the formula represents risks and calculates the amount of compensation the investor needs for taking a risk measure (beta) that compares the returns of the asset to the market once a period of time and to the market premium $\left(\mathrm{R}_{\mathrm{m}}-\mathrm{R}_{\mathrm{f}}\right)$.

Under CAPM, investment decision can be taken by comparing actual average return with minimum return required according to this model.

\section{Efficient Frontier Theory:}

The risk and return of all portfolios or stocks plotted in risk-return space would be dominated by efficient stocks or portfolios. Stocks may be selected randomly from capital market. To make effective combination in selection of stock, the concept of efficient frontier technique may be used. 


\section{Sharpe's optimal portfolio}

Sharpe had provided a model for the selection of appropriate securities in a portfolio. The selection of any stock is directly related to its excess return-beta ratio.

Where,

$$
\frac{\mathrm{Ri}-\mathrm{Rf}}{\beta \mathrm{i}}
$$

$\mathrm{Ri}=$ the expected return on stock $\mathrm{i}$

$\mathrm{Rf}=$ the return on the riskless asset

$\beta \mathrm{i}=$ the expected change in the rate of return on stock I associated with one unit change in the market return.

The excess return is the difference between the expected return on the stock and the riskless rate of interest such as the rate offered on the government security or Treasury bill. The excess return of beta ratio measures the additional return on a security (excess of the riskless asset return) per unit of systematic risk or non-diversifiable risk. This ratio provides a relationship between potential risk and reward. Ranking of the stocks are done on the basis of their excess return to beta. Portfolio managers would like to include stocks with higher ratios. The selection of the stock depends on a unique cut-off rate such that all stocks with higher ratios of Ri-Rf / $\beta \mathrm{i}$ are included and the stocks with lower ratios are left off. The cut-off point is denoted by $\mathrm{C}^{*}$. Later appropriate mix of securities can be done on the basis $\mathrm{Z}^{*}$.

\section{Objectives of the study:}

This paper mainly focuses on the BREXIT and its impact on overall economy of various countries and on Indian economy and also to guide the Investors regarding their Investment decision. To satisfy above broad objective, following objectives are identified.

1. To have detailed in depth knowledge on theoretical and historical background of BREXIT.

2. To evaluate impact of BREXIT on worlds various stock market performance.

3. To analyze the effect of BREXIT on performance of Indian top industries in Europe.

4. To estimate future direction of International trade and each other dependence by different countries.

5. To suggest on the basis of overall findings of the research survey for the investor to formulate better investment strategy.

\section{Need of the study:}

England played vital role in world economy since start of world history through their innovative trading strategy. British were key role player in European Union since its origin and most of the world's countries heavily depend on this iconic country for trade issues. Great idea of British-exit halted like stroke for many countries international trade. After Brexit economic condition and share market behavior of all counties started to see historic down. This is the right time to analyze the real impact of Brexit in different angle.

\section{Scope of the study:}

Brexit started to be like debating issue worldwide for many reason. Some of the countries are even after two month of Brexit are not able to regain their old popularities. Especially for the management and commerce students' Brexit has given wider scope to apply their world economy knowledge. This paper can be used by academician, students and researcher for better understanding of this historic concept.

\section{b. Sources of data:}

\section{Methodology}

Basically this paper depends upon secondary data but after severe restructuring using different models. Data has been collected form money market, rediff stock and respective websites of worlds different share markets for live share market prices. For the theoretical background and basic knowledge of Brexit even information gathered from reputed journals, magazines, newspapers and surfing net.

In this paper two broad category researches carried on which includes:

VI. Brexit and its impact on world's economy based on world's different share markets performance before and after Brexit. Before Brexit includes 2 years month end share market prices of world's top stock exchange's respective stock index. After Brexit includes share market month end price till the date (December $31^{\text {st }}$ ).

VII. Brexit and its impact on top Indian companies. For the purpose 8 selected companies stock market performance recorded systematically before and after Brexit on month end basis for last one year.

\section{c. Tools of Analysis:}

Final interpretation and suggestions have been drawn as result of the study after using critical financial and statistical techniques. In financial technique it includes concepts like return, risk, beta, Capital Asset Pricing Model, Efficient frontier technique and Sharpe's Optimal portfolio etc... Statistical technique includes table, graphs and pie charts. 


\section{Data Analysis and Interpretation}

Careful observation of returns of world's recognized stock exchanges before and after have revealed that Brexit is a short term incident which affected the entire stock market and mean while it had recovered soon so no need to be take any immediate steps just for Brexit. There is long live for share market investment and entire economy supports for long term investment and even this is the right time for new share market investors.

Table 1 and chart 1, observation can be done for risk or variation in the return before and after the Brexit. After the Brexit entire share markets throughout the globe began with stabilized return with very minimum variation which can create new hopes in investor for maximizing their future return with much variation. Finally this could be identified and proved that any single incidents no longer affect the share market movements except immediate short term. Investor should keep patience as a success strategy which made many reputed investor to shine in height of achievements.

Table 1: World's selectedmajor Stock market performance before and after Brexit.

\begin{tabular}{|c|c|c|c|c|}
\hline \multirow[t]{2}{*}{ Stock Exchanges } & \multicolumn{2}{|c|}{ Before Brexit } & \multicolumn{2}{|c|}{ After Brexit } \\
\hline & Return & Risk & Return & Risk \\
\hline BSE Sensex & -0.06 & 4.51 & -0.56 & 2.76 \\
\hline Nifty & 0.04 & 4.49 & -0.57 & 2.97 \\
\hline Nasdaq & 0.62 & 9.48 & 2.25 & 2.97 \\
\hline DAX & 0.45 & 6.08 & 2.89 & 3.24 \\
\hline Nikkei 225 & 0.08 & 5.45 & 3.80 & 3.23 \\
\hline FTSE & -0.26 & 3.27 & 1.42 & 2.13 \\
\hline KOSPI & 0.23 & 2.45 & 0.56 & 1.64 \\
\hline Taiwan Index & -2.34 & 8.31 & 0.79 & 1.68 \\
\hline CAC & 0.44 & 5.00 & 2.26 & 2.20 \\
\hline DJI(Dow jones Industrial Average) & 0.33 & 3.77 & 1.34 & 2.50 \\
\hline London Stock Exchange & 0.55 & 5.51 & -1.08 & 4.20 \\
\hline Deutsche Borse FRANKFURT Group & 0.40 & 6.47 & 2.92 & 3.12 \\
\hline Shanghai Stock Exchange & 0.06 & 10.28 & 1.06 & 3.36 \\
\hline HangSeng Stock Exchange & -0.61 & 0.02 & 0.76 & 3.62 \\
\hline Australian Security Exchange & 0.22 & 4.41 & 2.15 & 4.49 \\
\hline Straits Times & -0.98 & 4.94 & 0.19 & 1.91 \\
\hline S\&P/TSX Canada & -0.19 & 2.74 & 1.41 & 1.08 \\
\hline MICEX MOSCOW & -0.17 & 4.29 & 0.69 & 2.61 \\
\hline Tadawal Allshare [Saudi Arabia] & 0.89 & 3.84 & 2.08 & 2.88 \\
\hline AEX Amsterdam & -1.56 & 7.31 & 1.91 & 8.05 \\
\hline SMI Switzerland & -0.08 & 4.81 & 1.39 & 2.00 \\
\hline
\end{tabular}

Source: Authors Compilation

Chart 1: World's selected major stock market performance before and after Brexit.

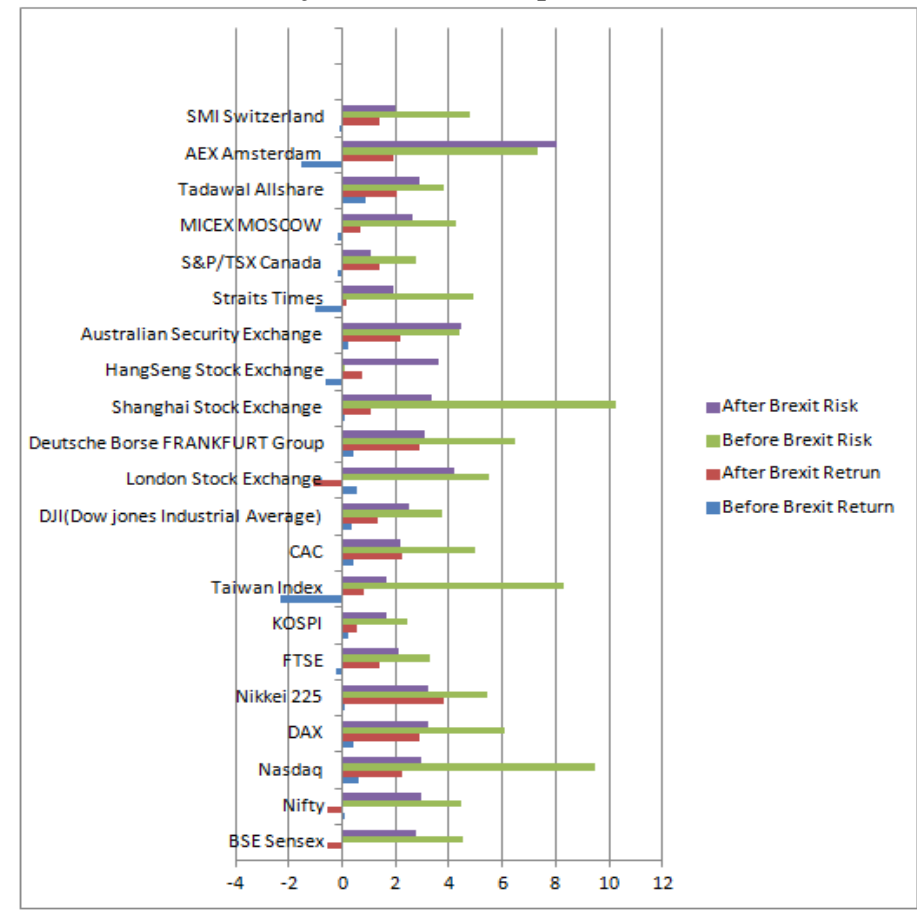

Source: Authors Compilation 
"Impact of Brexit on Global Economy"- An Attempt to Guide Investor Based on Empirical Study..

Table 2: Top selected Indian companies' performance before Brexit

\begin{tabular}{|c|c|c|c|c|c|c|c|}
\hline \multicolumn{8}{|c|}{ Before Brexit } \\
\hline Name & Return & Risk & Beta & $\begin{array}{c}\text { CAPM - expected } \\
\text { return }\end{array}$ & $\begin{array}{l}\text { Variation compared } \\
\text { with actual return }\end{array}$ & $\%$ of change & Ranks \\
\hline INFOSYS & 2.7 & 3.17 & 0.79 & 0.60 & 2.10 & 453.55 & 2 \\
\hline TCS & 1.39 & 7.97 & 1.18 & 0.62 & 0.77 & 223.26 & 3 \\
\hline Wipro & -0.36 & 5.92 & 0.67 & 0.59 & -0.95 & -61.34 & \\
\hline Tech Mahindra & 1.29 & 11.33 & 1.7 & 0.66 & 0.63 & 195.75 & \\
\hline Jet Air & -1.85 & 13.02 & 1.41 & 0.64 & -2.49 & -289.65 & \\
\hline HCL & -2.79 & 6.56 & 0.19 & 0.55 & -3.34 & -504.25 & \\
\hline Biocon & 7.39 & 13.07 & 0.9 & 0.60 & 6.79 & 1225.54 & 1 \\
\hline M\&M & 1.03 & 4.94 & 0.06 & 0.54 & 0.49 & 189.27 & \\
\hline
\end{tabular}

Source: Authors Compilation

Table 3: Top selected Indian companies' performance after Brexit:

\begin{tabular}{|c|c|c|c|c|c|c|c|}
\hline \multicolumn{8}{|c|}{ After Brexit } \\
\hline Name & Return & Risk & Beta & $\begin{array}{l}\text { CAPM - expected } \\
\text { return }\end{array}$ & $\begin{array}{l}\text { Variation compared } \\
\text { with actual return }\end{array}$ & $\%$ of change & \\
\hline INFOSYS & -2.57 & 3.17 & -0.89 & 0.48 & -3.05 & -537.99 & \\
\hline TCS & -1.02 & 3.29 & 0.54 & 0.58 & -1.60 & -176.53 & \\
\hline Wipro & -1.68 & 3.83 & -0.43 & 0.51 & -2.19 & -329.48 & \\
\hline Tech Mahindra & -1.03 & 5.97 & -1.04 & 0.47 & -1.50 & -220.46 & \\
\hline Jet Air & -5.77 & 8.41 & 2.69 & 0.73 & -6.50 & -792.26 & \\
\hline HCL & 1.47 & 3.47 & 0.08 & 0.55 & 0.92 & 269.43 & 2 \\
\hline Biocon & 3.7 & 4.66 & 1.27 & 0.63 & 3.07 & 588.33 & 1 \\
\hline M\&M & -1.35 & 4.57 & 1.19 & 0.62 & -1.97 & -216.59 & \\
\hline
\end{tabular}

Source: Authors Compilation

Chart 2: Representation of selected Indian companies return and risk before and after Brexit:

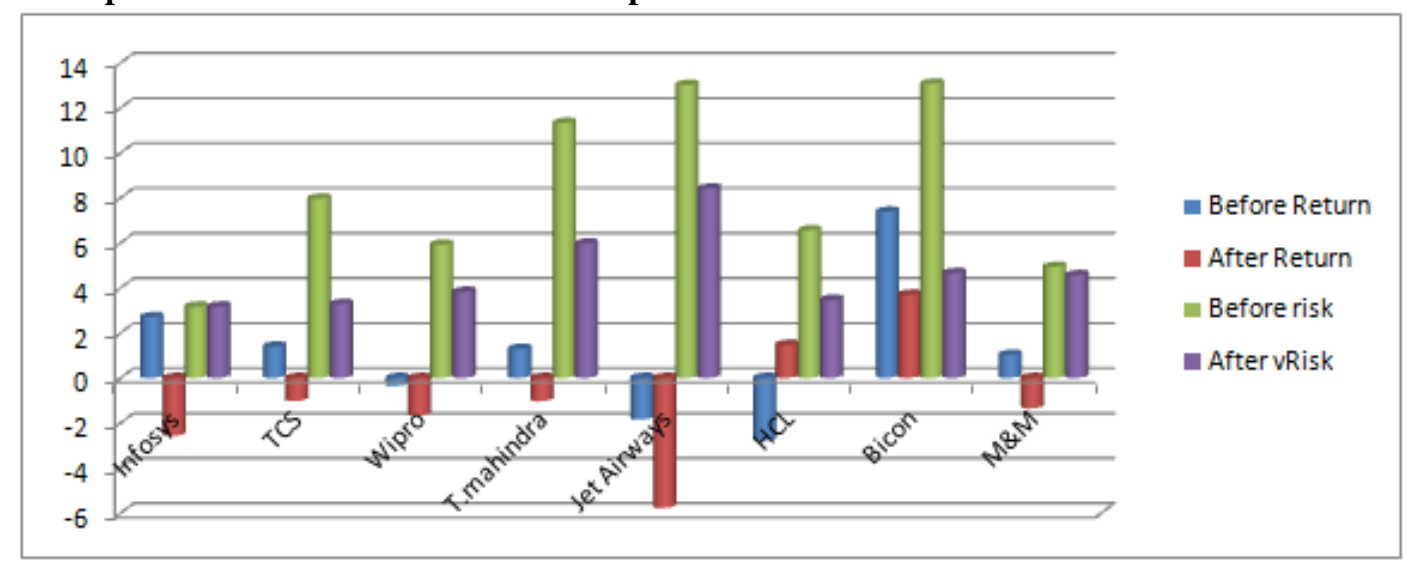

\section{Source: Authors Compilation}

In chart 2 it could be pointed return and risk of selected companies from Indian stock market before and after Brexit. Blue colored line indicates return before Brexit and red colored line after Brexit. Out of 8 companies 7 companies started to have heavy loss in their earning. It shows heavy negative influence of Brexit on share market performance. Green colored line indicates risk or variations in the return before Brexit and purple color indicates variation after Brexit. It could be noted chances of variation after Brexit reduced to maximum extent. This situation represents stabilization in variation since the immediate reaction got to end. This indicates future earning chances without much variation in respective companies.

Chart 3: Representation of selected Indian companies return and risk before and after Brexit:

Beta represents systematic risk. It suggests an investor regarding movement in individual stock keeping stock market index as a base. Brexit resulted in an historical variation on world's stock market where Indian stock market also isnot away from it. Shape of betavalue after Brexit showed high instability beyond the expectation and it made beta no more accurate indicator of future direction of individuals' shares. 


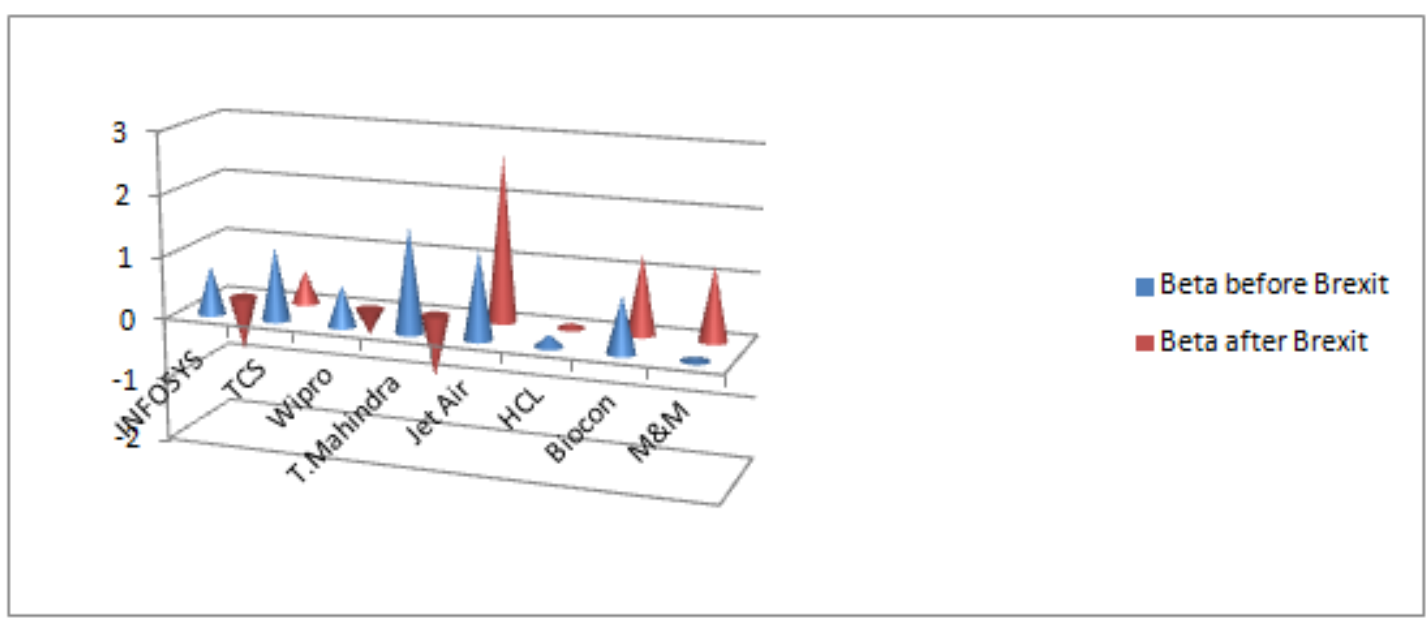

\section{Source: Authors Compilation}

\section{Capital Assets Pricing Model:}

CAPM model is designed to see what is the minimum return should security get to face current level of risk. In the table 2 and table 3 last four columns gives information about minimum required return for each security before and after Brexit under CAPM, variation compared with actual return, percentage of variation and finally top ranked securities which yield higher return than minimum required return.

Before Brexit five companies out of eight have yielded more than minimum required return, Biocon and Infosys companies placed in first two positions respectively with attractive return.

After the Brexit only two out of eight companies have positive return compared with minimum required for CAPM model. Biocon and HCL placed in first to positions respectively.

\section{Graph 1: Efficient frontier before Brexit:}

Efficient frontier helps to select securities on the basis of investors risk affordability. Graph 1 represents the characteristics of the efficient frontier before Brexit. Where, $\mathrm{X}$ axis represent standard deviation and $\mathrm{Y}$ axis represent return. Risk avoider can select Mahindra \& Mahindra, Risk neutral can opt for Infosys Company and finally risk lover can go for Biocon which has highest return with bit more expected variation.

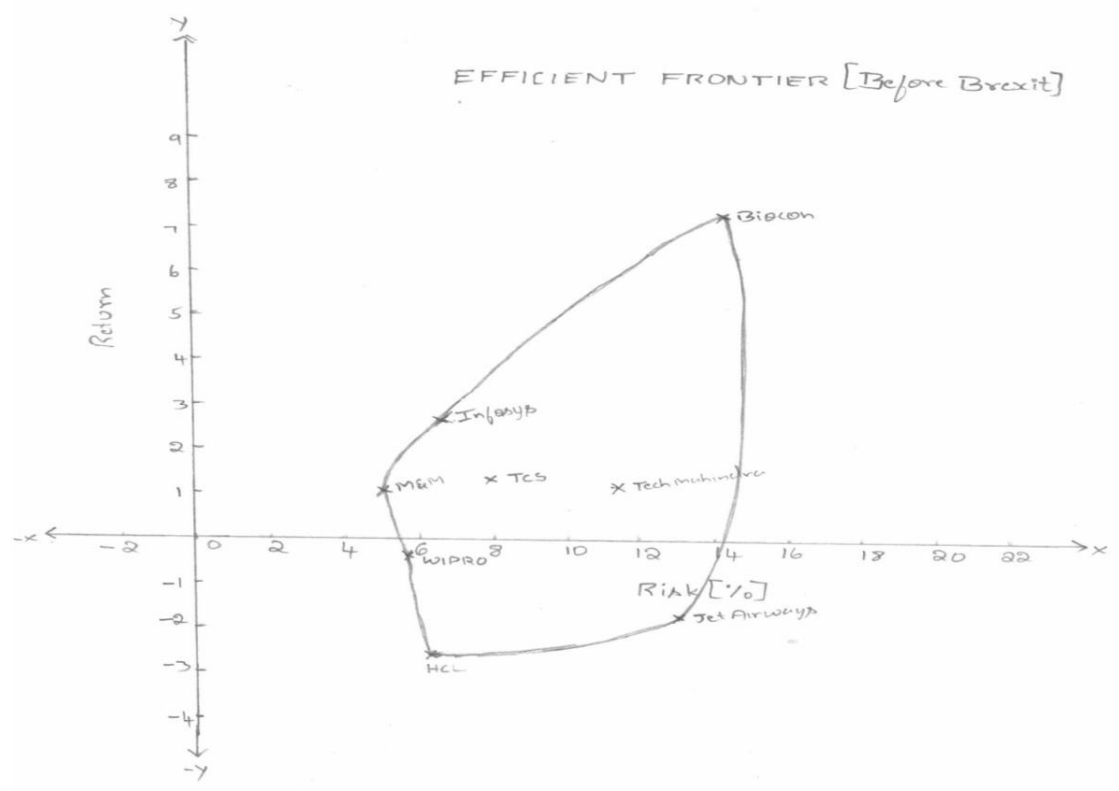


Graph 2: Efficient frontier after Brexit:

Shape of efficient frontier completely changed after Brexit with one more security in the place of Mahindra \& Mahindra and Infosys. Risk neutral and avoider can go for HCL and risk lover can opt for Biocon as before.

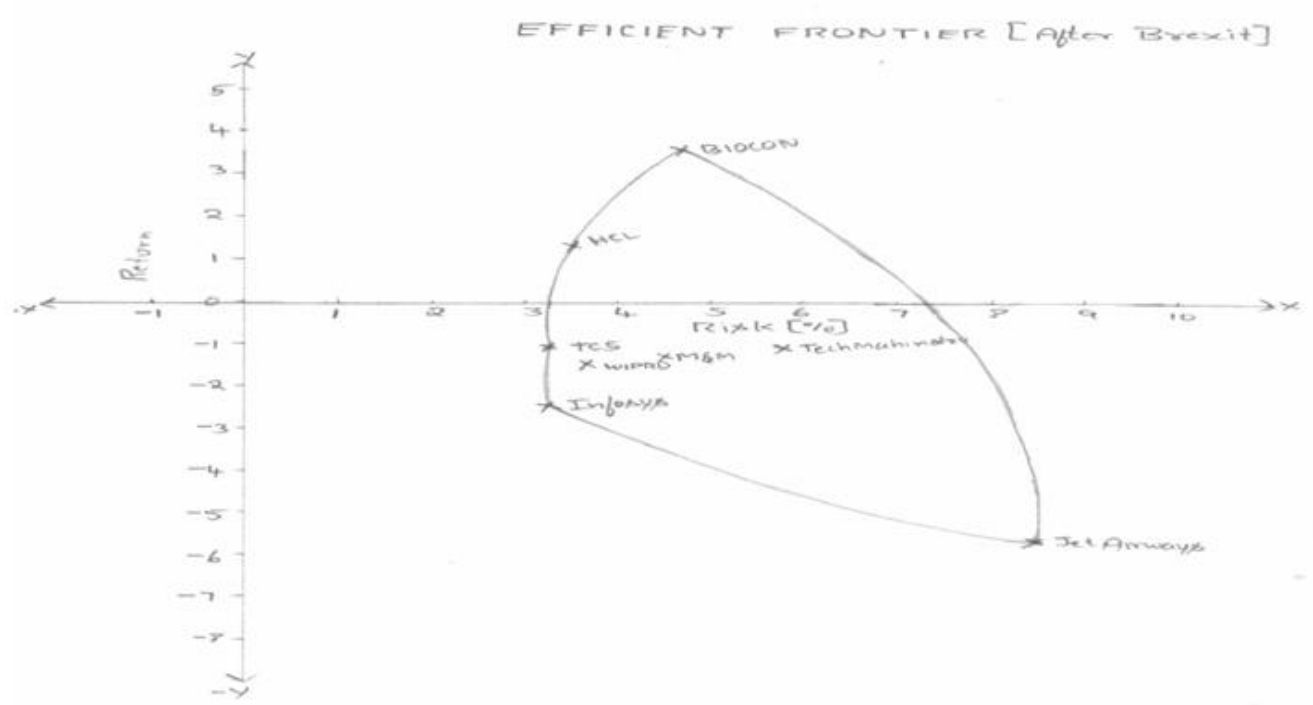

Table 4: Sharpe's Optimal Portfolio before and after Brexit:

\begin{tabular}{|c|c|c|c|c|c|}
\hline \multicolumn{6}{|c|}{ Sharpe's Optimal Portfolio } \\
\hline \multicolumn{3}{|c|}{ Before Brexit } & \multicolumn{3}{|c|}{ After Brexit } \\
\hline Company Name & Proportion of Investment & Return & Company Name & $\begin{array}{l}\text { Proportion of } \\
\text { Investment }\end{array}$ & Return \\
\hline M\&M & 0.29 & $\mathbf{1 . 0 3}$ & HCL & 0.79 & 1.47 \\
\hline Biocon & 0.71 & 7.39 & Wipro & 0.21 & -1.68 \\
\hline Portfolio Return & \multicolumn{2}{|l|}{$5.54 \%$} & Portfolio Return & \multicolumn{2}{|c|}{$0.81 \%$} \\
\hline
\end{tabular}

Source: Authors Compilation

(Note: All calculation done using MS Excel)

Chart 3: Sharpe's Optimal Portfolio before Brexit:

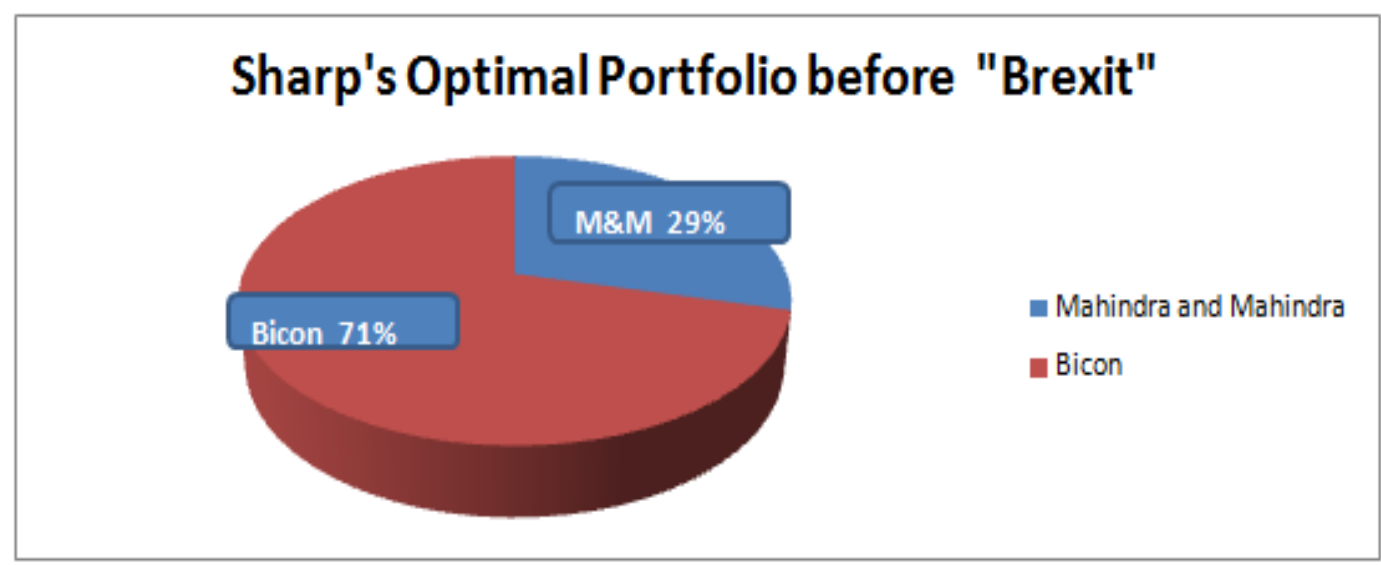

Source: Authors Compilation

Table 4 and chart 3 gives the interpretation on how to frame the most attractive combination of securities for well diversified investment out of available eight securities under Sharpe's optimal portfolio. Before Brexit in the portfolio it was occupied with Mahindra \& Mahindra and Biocon with $29 \%$ and $71 \%$ respectively. This portfolio could yield $5.54 \%$ of return each month. 
Chart 4: Sharpe's Optimal Portfolio after Brexit:

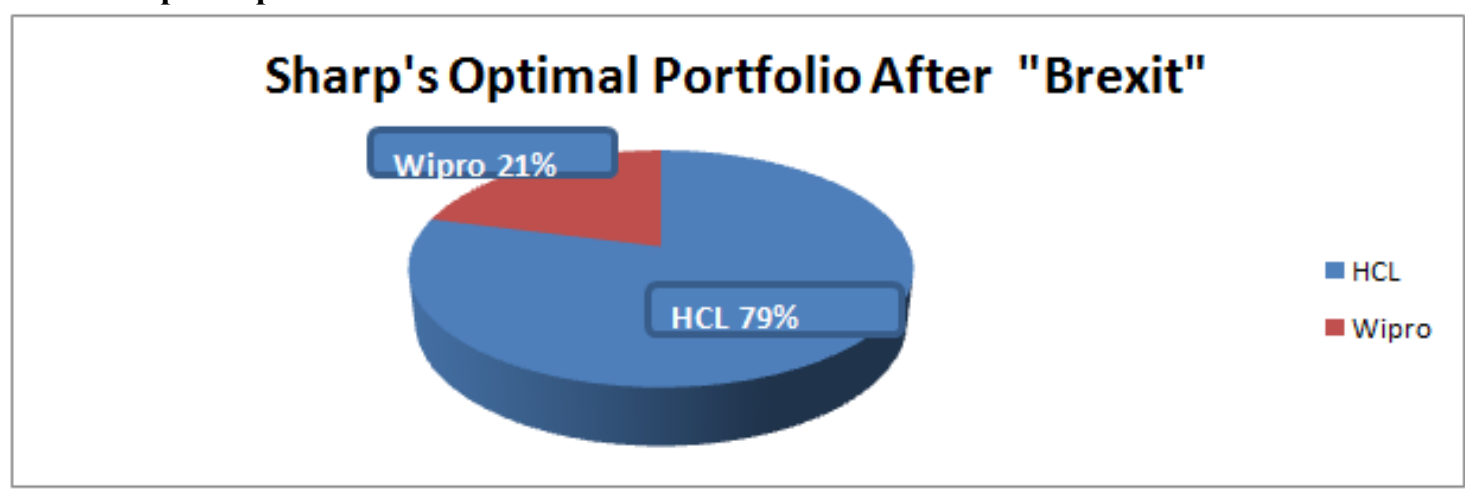

\section{Source: Authors Compilation}

Table 4 and chart 4gives details on attractivecombination of securities after Brexit under Sharpe's optimal portfolio which is occupied by Wipro $21 \%$ and HCL 79\% respectively but cause for less return of just $0.81 \%$ of return at the end of each month. It proves there is impact of Brexit in short run but will recover once the confidence is filled in investors mind.

\section{Suggestions}

1. "Purchase when everyone sell and sell when everyone purchase", through the study it revealed that Brexit made tremendous change in share market by reaching lower depth of earning because of heavy exit by investors. New investor and existed investor could use this as an opportunity for long run wealth creation by having systematic investment.

2. Study has shown investor gets panic for incidents immediately which cause for heavy loss or opportunity cost of making profit in future. It is suggestible to investor not to get panic and move towards market; instead they can take suggestions of expert or wait for recovery.

3. People can go for portfolio investment which facilitates appropriate return in any situation adding the advantage of diversification.

4. Investment after making economy analysis, industry analysis and company analysis proved better prospectus for selecting right securities.

5. Financial techniques like return, risk, beta, CAPM, Efficient frontier and Sharp's optimal portfolio can be utilized to be a professional investor. Increasing knowledge is acting like right weapon to fight against market.

\section{Conclusion}

Indian share market coverage is not more than $10 \%$ of total population but in developed countries this percentage goes above 50\%. This showsthe possibility of huge upward movement and opportunities in the Indian stock market to the prospective investor. Lack of education and awareness are one of the greatest threats which made stock market look like a risky avenue for investment to the common and middle class people. One can blend three ingredients for success in security market that is time, experience and knowledge to get sure return. Government and educational institution should try to give practical exposure to the higher education students about the share market investment.

\section{Bibliography}

[1]. Brown, G. (2016), Leading Not Leaving: The Patriotic Case for Britain in Europe, Selkirk: Deerpark Press.

[2]. Kierzenkowski, R., N. Pain, E. Rusticelli and S. Zwart (2016), The Economic Consequences of Brexit: A Taxing Decision, OECD Economic Policy Paper 16.

[3]. http://www.federalreserve,gov/newsevents/speech/yellen20160606a.htm

[4]. http://m.moneycontrol.com

[5]. In.investing.com/mobile/

[6]. Wikipedia 